\title{
APLIKASI PEMETAAN LOKASI PELAYANAN KESEHATAN DI KABUPATEN WAY KANAN
}

\author{
Hayatunnufus $^{1)}$, Fikri Ari Wibowo ${ }^{2)}$ \\ ${ }^{1}$ Program Studi Ilmu Komputer, Universitas Sumatera Utara \\ ${ }_{2}^{2}$ Program Studi Informatika, Universitas Teknokrat Indonesia \\ ${ }^{1}$ Jalan Dr. T. Mansur No. 9, Kampus Padang Bulan, Medan, Sumatera Utara \\ ${ }^{2}$ Jalan Z.A. Pagar Alam No. 9-11 Labuhan Ratu Bandar Lampung \\ Email: ${ }^{1}$ hayatunnufus@usu.ac.id, ${ }^{2}$ fikri.ariwibowo@gmail.com
}

\begin{abstract}
Health Services is a place to organize health efforts. In this study found several problems regarding health service information, such as the official website of the Way Kanan district, which only provides information on a number of large hospitals, not all health service locations are known by the public, both from the Way Kanan District or from outside the city, and if you are looking to use The Google Maps application still has unregistered health service locations, so that this application can complement data that has not been registered in the Google Maps application so that people can know better and facilitate the search for health locations on the Way Kanan. This research uses interview, observation and literature study data collection methods. The design method used is prototype and the testing technique used is ISO / TEC 25010. This research resulted in an application mapping the location of health services in the Way Kanan District based on Android, and can display a list of information on Hospitals, Health Centers, Main Clinics and Looking Map. In addition, system testing is carried out namely Functional Suitability and Usability aspects. Based on testing the Functional Suitability Aspect gets $100 \%$ results and Usability gets $81.6 \%$ results. The conclusion of the test results by testing ISO / TEC 25010 shows that this application can help the community and can be said to be successful so that the system is declared very feasible for use by the Way Kanan community.
\end{abstract}

Key Words : Android, Google Maps API, Way Kanan, Health Service

\begin{abstract}
Abstrak
Layanan Kesehatan merupakan tempat menyelenggarakan upaya kesehatan. Dalam penelitian ini ditemukan beberapa permasalahan mengenai informasi layanan kesehatan, seperti website resmi kabupaten Way Kanan hanya memberikan informasi beberapa rumah sakit besar, tidak semua lokasi layanan kesehatan diketahui oleh masyarakat baik yang berasal dari Kabupaten Way Kanan maupun yang berasal dari luar kota serta jika mencari menggunakan Aplikasi Google Maps masih ada lokasi pelayanan kesehatan yang tidak terdaftar, sehingga adanya aplikasi ini bisa melengkapi data yang belum terdaftar di Aplikasi Google Maps sehingga masyarakat bisa lebih tahu serta mempermudah pencarian lokasi kesehatan di Way Kanan. Penelitian ini menggunakan metode pengumpulan data wawancara, observasi dan studi literatur. Metode perancangan yang digunakan adalah prototype dan teknik pengujian yang digunakan adalah ISO/TEC 25010. Dari penelitian ini menghasilkan aplikasi pemetaan lokasi pelayanan kesehatan di Kabupaten Way Kanan berbasis Android, serta dapat menampilkan daftar informasi Rumah Sakit, Puskesmas, Klinik Utama dan Lihap Map. Selain itu pengujian sistem yang dilakukan yaitu aspek Functional Suitability dan Usability. Berdasarkan pengujian Aspek Functional Suitability mendapatkan hasil 100\% dan Usability mendapatkan hasil 81.6\%. Kesimpulan hasil pengujian dengan pengujian ISO/TEC 25010 menunjukkan bahwa aplikasi ini dapat membantu masyarakat dan dapat dikatakan berhasil sehingga sistem dinyatakan sangat layak untuk digunakan oleh masyarakat Way Kanan.
\end{abstract}

Kata Kunci : Android, Google Maps API, Way Kanan, Pelayanan Kesehatan 


\section{Pendahuluan}

Layanan Kesehatan merupakan tempat menyelenggarakan upaya kesehatan [1]. Berkaitan dengan informasi fasilitas pelayanan kesehatan, website resmi kabupaten Way Kanan hanya memberikan informasi beberapa rumah sakit besar, website resmi kabupaten Way Kanan hanya memberikan informasi beberapa rumah sakit besar, tidak semua lokasi layanan kesehatan diketahui oleh masyarakat baik yang berasal dari Kabupaten Way Kanan maupun yang berasal dari luar kota dan jika mencari menggunakan Aplikasi Google Maps masih ada lokasi pelayanan kesehatan yang tidak terdaftar dikarenakan minimnya informasi yang tersedia,. Hal ini disebabkan karena kurangnya informasi tentang layanan kesehatan di Kabupaten Way Kanan. Berdasarkan pemaparan diatas maka perlu adanya solusi untuk menangani permasalahan tersebut yaitu dengan dibangun Aplikasi Pemetaan Lokasi Pelayanan Kesehatan Di Kabupaten Way Kanan". DSalam sistem tersebut dapat memberikan informasi kepada masyarakat luas khususnya daerah Way Kanan tentang penyedia layanan kesehatan secara tepat melalui sebuah aplikasi mobile berbasis android.

\section{Landasan Teori}

\subsection{Pelayanan Kesehatan}

Pelayanan kesehatan menurut Departemen Kesehatan Republik Indonesia Tahun 2009 (Depkes RI) yang tertuang dalam Undang- Undang Kesehatan tentang kesehatan ialah setiap upaya yang diselenggarakan sendiri atau secara bersama-sama dalam suatu organisasi untuk memelihara dan meningkatkan kesehatan, mencegah dan menyembuhkan penyakit serta memulihkan kesehatan, perorangan, keluarga, kelompok ataupun masyarakat [2].

\subsection{Google Map Service}

Google Map Service adalah sebuah jasa peta global virtual gratis dan online yang disediakan oleh perusahaan Google. Google Maps yang dapat ditemukan di alamat http://maps.google.com. Google Maps menawarkan peta yang dapat diseret dan gambar satelit untuk seluruh dunia. Google Maps juga menawarkan pencarian suatu tempat dan rute perjalanan[3].

\subsection{Android}

Menurut (Safaat, 2012) Android adalah sebuah sistem operasi yang sengaja diciptakan untuk perangkat mobile berbasis Linux yang mencakup sistem operasi, middleware, dan aplikasi [4].

\subsection{Prototype}

Menurut Rosa dan Shalahuddin (2018), "Model prototype dapat digunakan untuk menyambung ketidakpahaman pelanggan mengenai hal teknis dan memperjelas spesifikasi kebutuhan yang diinginkan pelanggan kepada pengembang perangkat lunak"[5]. Tahapan yang terdapat pada metode pengembangan perangkat lunak Protoype dapat dilihat pada Gambar berikut :

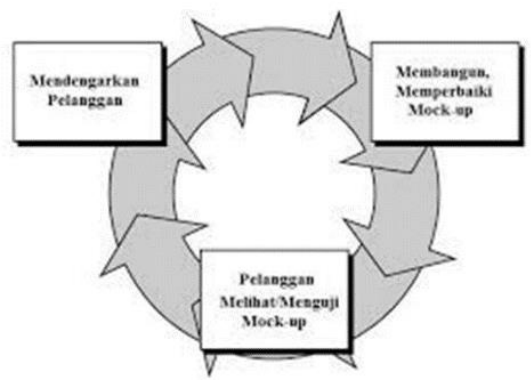

Gambar 1 Ilustrasi model prototype.

(Sumber : Rosa A.S, M. Shalahudin, 2018)

Tahapan-tahapan dalam pembuatan prototype yaitu:

1. Mendengarkan Pelanggan. Pada tahap ini, dilakukan pengumpulan kebutuhan dari sistem dengan cara mendengar kebutuhan pelanggan sebagai pengguna sistem perangkat lunak untuk menganalisis serta mengembangkan kebutuhan pengguna.

2. Merancang dan Membuat Prototype. Pada tahap ini, dilakukan perancangan dan pembuatan prototype sistem yang disesuai dengan kebutuhan pengguna.

3. Uji Coba. Pada tahap ini, dilakukan pengujian prototype sistem oleh pengguna kemudian dilakukan evaluasi sesuai dengan kekurangankekurangan dari kebutuhan pelanggan. Jika sistem sudah sesuai dengan prototype, maka sistem akan diselesaikan sepenuhnya. Namun, jika masih belum sesuai kembali ke tahap pertama.

\subsection{ISO 25010}

ISO 25010 adalah salah satu model pengujian dan evaluasi kualitas perangkat lunak yang merupakan bagian dari Software Product Quality Requirements and Evaluation (SQuaRE). Teknik pengujian ini berkaitan dengan model kualitas perangkat lunak yang merupakan pengembangan dari model sebelumnya ISO 9126 dengan penambahan beberapa struktur dan bagian dari standar model kualitas [6].

Secara keseluruhan model kualitas perangkat lunak ISO/IEC 25010 terbagi menjadi 8 karakteristik yaitu: Functional Suitability, Performance Efficiency, Compatibility, Usability, Reliability, Security, Maintainability, dan Portability [7].

Dari delapan karakteristik kualitas sebuah aplikasi tersebut, penulis tetapkan hanya tiga karakteristik saja yang dijadikan sebagai variabel pengujian pada 
penelitian ini. Tiga karateristik tersebut yaitu Functional Suitability, dan Usability.

\section{Analisis Dan Perancangan Sistem}

\subsection{Pengumpulan Data}

Penyusunan penelitian ini tentu membutuhkan berbagai keterangan-keterangan lengkap. Peneliti mengumpulkan data-data tersebut dengan berbagai metode, yaitu:

a. Wawancara. Pengumpulan data dengan metode wawancara yaitu metode pengumpulan data dengan cara tanya jawab secara langsung ke dinas kesehatan di kabupaten Waykanan.

b. Observasi. Mempelajari segala sesuatu yang berhubungan dengan sistem yang akan dibangun. Mengamati secara langsung bagaimana masyarakat dalam mencari informasi mengenai pencarian informasi layanan kesehatan di Way Kanan.

c. Studi Literatur. Mempelajari segala sesuatu yang berhubungan dengan sistem yang akan dibangun. Mengamati secara langsung bagaimana masyarakat dalam mencari informasi mengenai pencarian informasi layanan kesehatan di Way Kanan.

\subsection{Analisis Kebutuhan}

1. Kebutuhan Fungsional. Kebutuhan fungsional merupakan kebutuhan berupa data-data yang dibutuhkan untuk menginputkan fungsi dari sistem, berikut adalah kebutuhan fungsional :

a. Admin. Admin merupakan aktor yang dapat mengelola data seperti:

1) Mengelola data Rumah Sakit

2) Mengelola data Puskesmas

3) Mengelola data Klinik Utama

b. Pengguna (User)

1) User dapat melihat informasi lokasi kesehatan di Kabupaten Way Kanan.

2) User dapat melihat informasi Rumah sakit, Puskesmas dan Klinik.

3) User dapat menampilkan informasi jarak lokasi, arah lokasi dan waktu yang dibutuhkan untuk menempuh lokasi.

4) User apat melakukan fungsi zoom-in dan zoom-out pada peta.

2. Kebutuhan Non-Fungsional

a. Sistem dapat dijalankan pada smartphone dengan beberapa versi android.

b. Peta tampil jika dihubungkan dengan internet.

c. Besarnya program dari sistem maksimal sebesar 50 MB.

d. Aplikasi memiliki tampilan / interface yang mudah dimengerti pengguna.
1. Use Case Diagram

Use case diagram merupakan gambaran skenario dari interaksi antara pengguna dengan sistem [8]. Use case diagram menggambarkan hubungan antara aktor dan kegiatan yang dapat dilakukannya terhadap aplikasi. Use case yang digunakan dapat dilihat pada gambar berikut :

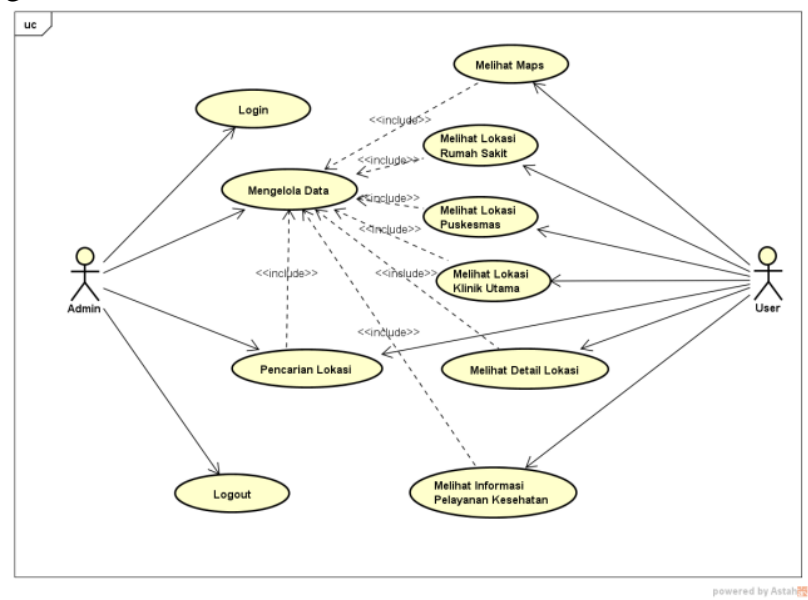

Gambar 2. Use Case Diagram

2. Activity Diagram Admin

Berikut adalah activity diagram dari sistem yang akan dibangun.

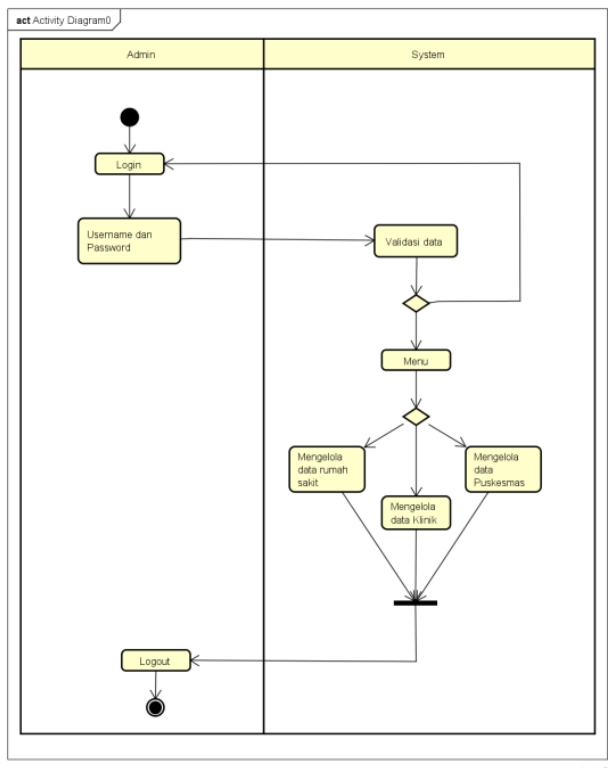

Gambar 3. Activity Diagram Admin

2. Activity Diagram User

Berikut adalah activity diagram user dari sistem yang akan dibangun.

\subsection{Perancangan Sistem}




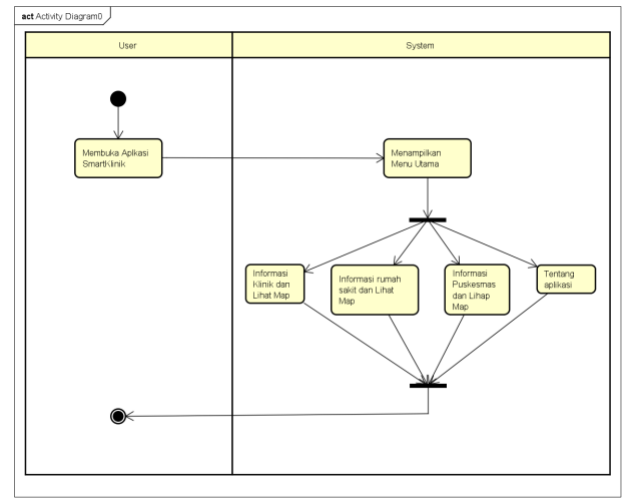

Gambar 4. Activity Diagram User

3. Class Diagram

Class Diagram menggambarkan struktur dan deskripsi class, package dan objek beserta hubungan satu sama lain [9]. Class diagram pada aplikasi pemetaan lokasi kesehatan di Kabupaten Way Kanan disajikan pada gambar berikut :

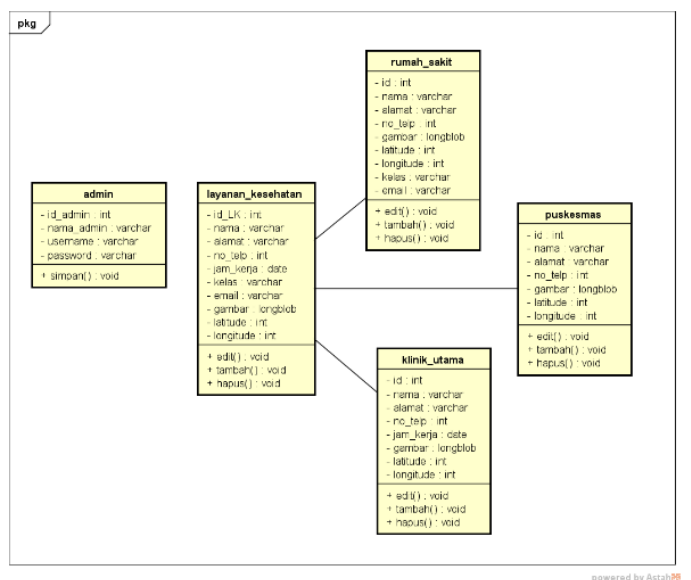

Gambar 5. Class Diagram

\section{Implementasi}

\subsection{Form login admin (web)}

Login password merupakan tampilan pertama pada saat program dijalankan. Tampilan form ini, berfungsi untuk keamanan data di penguna diminta untuk meng-inputkan password yang telah ditentukan sebelumnya. Berikut adalah Form login yang terdapat pada gambar 6 .

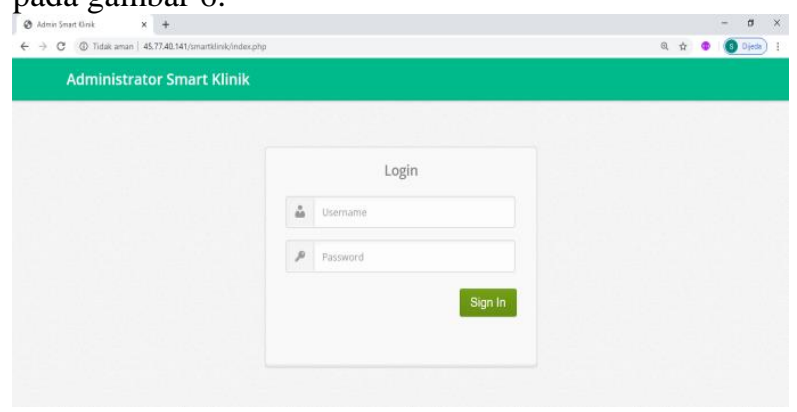

Gambar 6. Login Admin

\subsection{Menu Utama}

Form menu utama admin merupakan tampilan yang berfungsi untuk melihat menu - menu yang akan diakses oleh admin terdapat beberapa menu yaitu beranda, data rumah sakit, data puskesmas, data klinik utama, dan ubah password. Form menu utama admin dapat dilihat pada Gambar 7.



Gambar 7. Menu Utama

\subsection{Form Menu Data Rumah Sakit}

Form menu input Data Rumah Sakit merupakan tampilan yang berfungsi untuk menginputkan data rumah sakit pada Aplikasi Pemetaan Lokasi Pelayanan Kesehatan Kabupaten Way Kanan. Form data rumah sakit dapat dilihat pada gambar 8 .

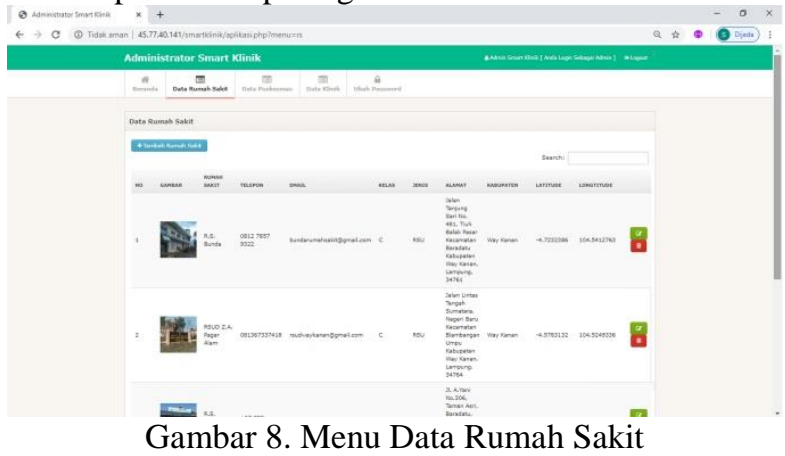

\subsection{Form Menu Data Puskesmas}

Form menu input Data Rumah Puskesmas merupakan tampilan yang berfungsi untuk menginputkan data rumah sakit pada Aplikasi Pemetaan Lokasi Pelayanan Kesehatan Kabupaten Way Kanan. Form data puskesmas dapat dilihat pada gambar 9 berikut.



Gambar 9. Menu Data Puskesmas

\subsection{Form menu data Klinik}

Form menu input Data Klinik Utama merupakan tampilan yang berfungsi untuk menginputkan data 
rumah sakit pada Aplikasi Pemetaan Lokasi Pelayanan Kesehatan Kabupaten Way Kanan. Form data Klinik Utama dapat dilihat pada gambar 10 .

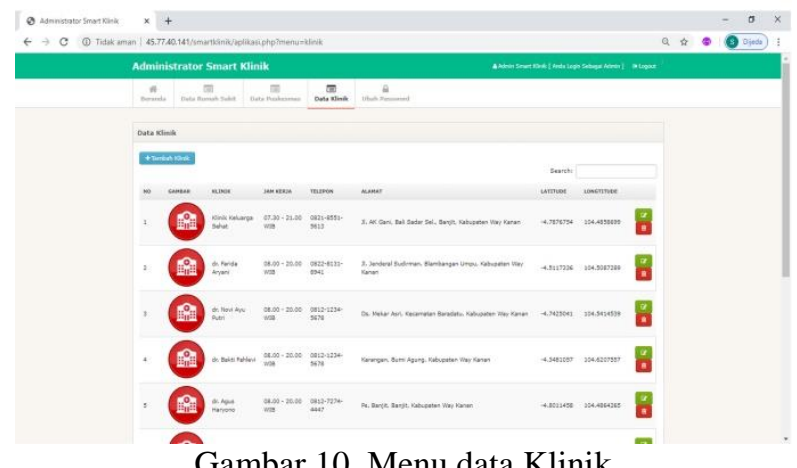

\subsection{Menu Ubah Password}

Form menu ubah password merupakan menginputkan password baru jika password lama sudah tidak aman pada saat ingin masuk ke dalam sistem. Form ubah password dapat dilihat pada gambar 11.

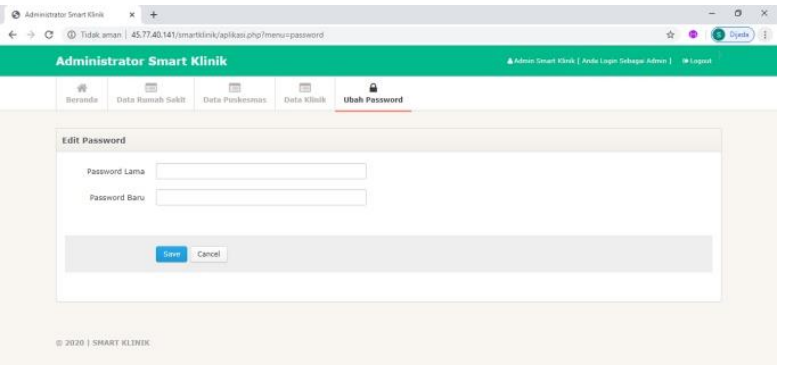

Gambar 11. Ubah password

\subsection{Form Menu Utama (Mobile)}

Form menu utama merupakan tampilan yang berfungsi untuk melihat menu-menu yang akan diakses oleh user. Terdapat beberapa menu Rumah sakit, puskesmas, klinik utama, lihat map dan tentang. Menu utama dapat dilihat pada gambar 12 .

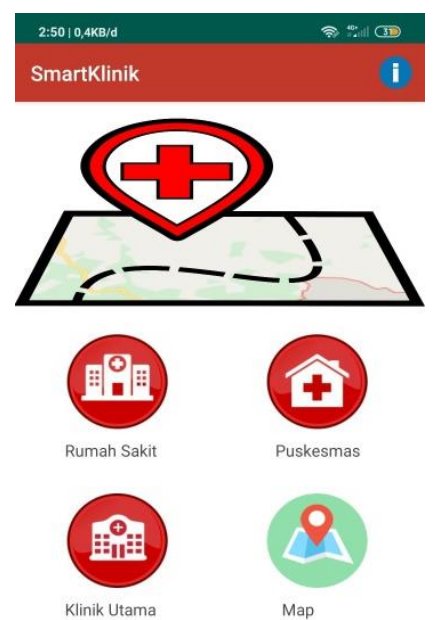

\section{Gambar 12. Menu Utama}

\subsection{Menu Daftar Rumah Sakit}

Form menu rumah sakit merupakan tampilan yang berfungsi untuk menampilkan daftar rumah sakit yang tersedia di Kabupaten Way Kanan. Form menu rumah sakit dapat dilihat pada gambar 13 .

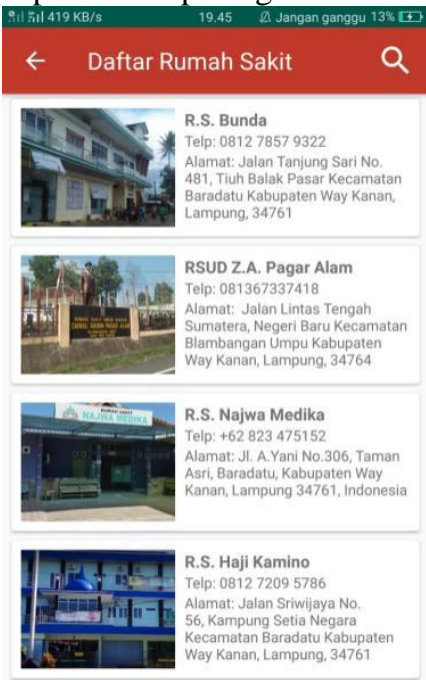

Gambar 13. Daftar Rumah Sakit

\subsection{Form Detail Rumah Sakit}

Form detail rumah sakit merupakan tampilan yang berfungsi untuk menampilkan informasi detail yang ada di rumah sakit. Form detail rumah sakit dapat dilihat pada gambar 14 .



R.S. Haji Kamino

$$
\begin{aligned}
& \text { Alamat: Jalan Sriwijaya No. 56, Kampung Setia } \\
& \text { Negara Kecamatan Baradatu Kabupaten Way } \\
& \text { Kanan, Lampung, } 34761 \\
& \text { Kabupaten: Way Kanan } \\
& \text { Telp: } 081272095786 \\
& \text { Email: rs_hajikamino@yahoo.co.id } \\
& \text { Jenis: RSU } \\
& \text { Kelas: C } \\
& \text { LIHAT MAP }
\end{aligned}
$$

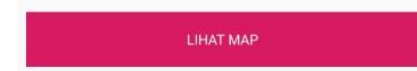

Gambar 14. Detail Rumah Sakit

\subsection{Form Daftar Puskesmas}

Form menu puskesmas merupakan tampilan yang berfungsi untuk menampilkan daftar puskesmas yang tersedia di Kabupaten Way Kanan. Form menu puskesmas dapat dilihat pada gambar 15 . 




Gambar 15. Daftar Puskesmas

\subsection{Detail Puskesmas}

Form detail puskesmas merupakan tampilan yang berfungsi untuk menampilkan alamat dan nomor telepon puskesmas. Form detail puskesmas dapat dilihat pada gambar 16 .

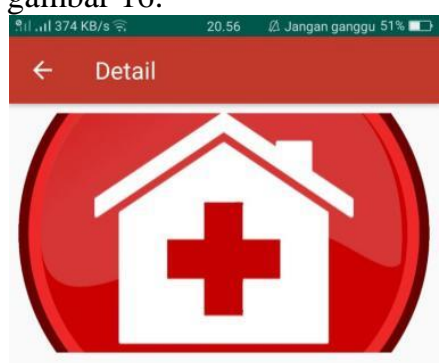

Puskesmas Baradatu

Alamat: Jl. Gajah Mada No.185 Ds. Tiuh Balak, Kec. Baradatu

Telp. 0853-8110-0306

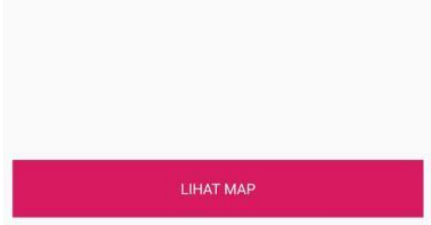

Gambar 16. Detail Puskesmas

\subsection{Daftar Klinik}

Form menu klinik utama merupakan tampilan yang berfungsi untuk menampilkan daftar klinik yang tersedia di Kabupaten Way Kanan. Form menu klinik utama dapat dilihat pada gambar 17.

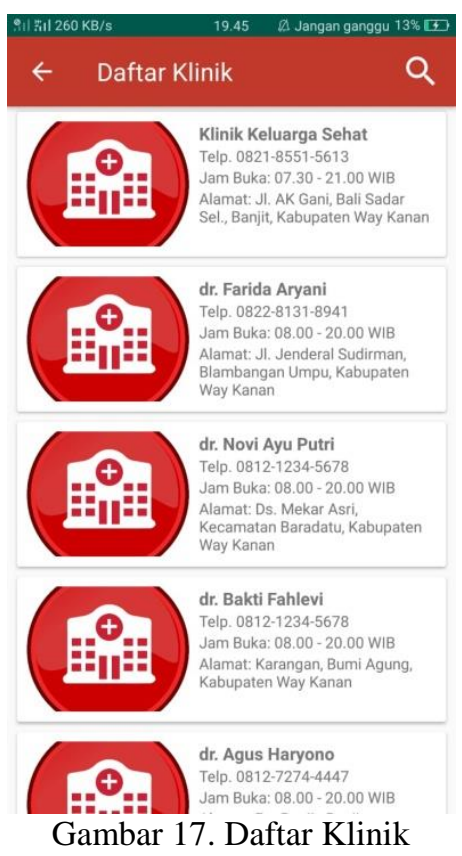

\subsection{Detail Klinik}

Form detail Klinik utama merupakan tampilan yang berfungsi untuk menampilkan alamat, nomor telepon dan jam buka klinik. Form detail klinik utama dapat dilihat pada gambar 18 .

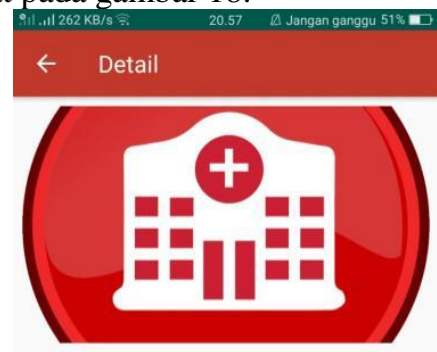

Klinik Keluarga Sehat

Alamat: Jl. AK Gani, Bali Sadar Sel., Banjit. Kabupaten Way Kanan

Telp. 0821-8551-5613

Jam Buka: $07.30-21.00$ WIB

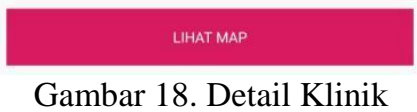

\subsection{Tampilan Lihat Map}

Pada menu ini akan ditampilkan maps yang menunjukkan seluruh lokasi pelayanan kesehatan berupa titik lokasi serta menunjukkan lokasi dari posisi user ke pelayanan kesehatan terdekat.. Layout menu Lihat map dapat dilihat pada gambar 19. 
tanggapan responden sebesar $100 \%$ berada dalam kriteria Baik. Sehingga berdasarkan hasil skor diatas dapat disimpulkan bahwa tingkat functionality aplikasi dalam kriteria Baik, dengan persentase sebesar $100 \%$.

\section{Usability}

Untuk standar skenario penelitian kebutuhan user menggunakan standar kualitas ISO 25010 usability testing, adapun pengujian usability dilakukan terhadap 10 responden melalui media kuisioner yang dapat dilihat didaftar lampiran. Jumlah pernyataan dalam kuesioner tersebut yaitu 15 pernyataan dengan menggunakan skala $\mathrm{SS}=5, \mathrm{~S}=4, \mathrm{~N}=3, \mathrm{TS}=2, \mathrm{STS}=1$. Hasil pengujian aspek usability dapat dilihat pada tabel 1 berikut :

aplikasi pemetaan lokasi kesehatan di Kabupaten Way Kanan serta informasi pengembang. Perancangan form menu tentang dapat dilihat pada gambar 20.

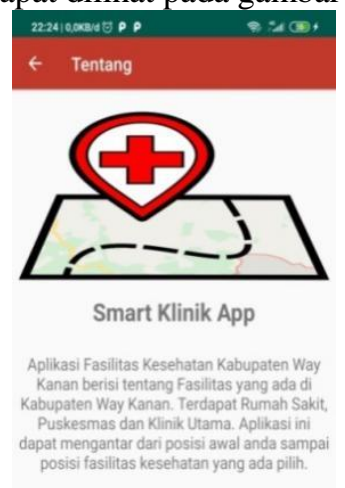

\begin{tabular}{|l|c|c|c|c|}
\hline Sub-Karakteristik & Operability & Leambility & Appropriateness & User interface \\
\hline Total & 219 & 230 & 91 & 107 \\
\hline Skor Maksimum & 250 & 250 & 100 & 150 \\
\hline Persentase & $87,6 \%$ & $92 \%$ & $91 \%$ & $71,4 \%$ \\
\hline Total Persentase & \multicolumn{5}{|c|}{$85,5 \%$} \\
\hline
\end{tabular}

Tabel 1. Hasil pengujian aspek usability

Didapatkan hasil kelayakan tiap sub aspek usability dari 10 responden, dengan hasil yang dapat dilihat pada tabel 2 sebagai berikut :

Tabel 2. Hasil Kelayakan sub Karakteristik Usability

\begin{tabular}{|l|l|c|l|}
\hline No & Sub-Karakteristik & Persentase & Tingkat Kelayakan \\
\hline 1. & Operability & $87,6 \%$ & Sangat Layak \\
\hline 2. & Learnbility & $92 \%$ & Sangat Layak \\
\hline 3. & Appropriateness recognizability & $91 \%$ & Sangat Layak \\
\hline 4. & User interface aesthetics & $71,4 \%$ & Layak \\
\hline
\end{tabular}

\section{Hasil dan Pembahasan}

\subsection{Pengujian ISO 25010}

Pengujian sistem dilakukan untuk memeriksa dan memastikan bahwa sistem telah berfungsi sesuai dengan yang diharapkan. Kemudian pada penelitian ini dilakukan pengujian ISO 25010 berdasarkan dua karakteristik yaitu Functional Suitability, dan Usability.

\section{Functional Suitability}

Pada pengujian functional suitability kuesioner diisi oleh 1 (data terlampir) orang untuk mengetahui apakah fungsi-fungsi pada aplikasi dapat berjalan dengan benar, setiap orang memberikan 1 point apabila hasil functional suitability yang dilakukan sukses. Selanjutnya dilakukan perhitungan persentase untuk pengujian aspek functional suitability yaitu sebagai berikut :

$$
\begin{array}{ll}
\text { Persentase } & =\frac{\text { skor hasil pengujian }}{\text { skor tertinggi }} \times 100 \% \\
\text { Sukses } & =\frac{27}{27} \times 100 \%=100 \%
\end{array}
$$

Hasil skor didapat dari hasil responden setuju bahwa aplikasi memiliki nilai fungsionalitas yang baik sesuai fungsi-fungsi yang dimilikinya. Persentase skor

Selanjutnya dilakukan perhitungan persentase untuk pengujian aspek usability secara keseluruhan dari data hasil pengujian menggunakan rumus :

$$
\begin{aligned}
\text { Persentase usability } & =\frac{\text { skor hasil pengujian }}{\text { skor tertinggi }} \times 100 \% \\
& =\frac{612}{750} \times 100 \%=81,6 \%
\end{aligned}
$$

\section{Analisis hasil Pengujian}

Perancangan sistem informasi pelayanan pengaduan masyarakat berbasis web diuji dalam tahap uji kualitas software ISO 25010 (Functional Suitability, dan Usability). Hasil pengujian Aplikasi Pemetaan Lokasi Pelayanan Kesehatan di Kabupaten Way Kanan dapat dilihat pada tabel 3 sebagai berikut:

\begin{tabular}{|l|c|}
\hline \multicolumn{1}{|c|}{ Aspek } & Hasil \\
\hline Functional Usability & $100 \%$ \\
\hline Usability & $81,6 \%$ \\
\hline TOTAL & $90,8 \%$ \\
\hline
\end{tabular}

Tabel 3. Hasil Pengujian 


\section{Kesimpulan dan Saran}

\subsection{Kesimpulan}

Berdasarkan uraian dari bab-bab yang telah dijelaskan, penulis menarik kesimpulan dari beberapa masalah yaitu :

1. Pembuatan aplikasi ini menggunakan metode prototype yang melalui beberapa tahap. Tahapan pertama mendengarkan pelanggan yaitu pada tahapan ini dilakukan pengumpulan kebutuhan dari sistem dengan cara mendengar kebutuhan pelanggan sebagai pengguna sistem perangkat lunak untuk menganalisis serta mengembangkan kebutuhan pengguna, merancang dan membuat prototype yaitu pada tahap ini, dilakukan perancangan dan pembuatan prototype sistem yang disesuai dengan kebutuhan pengguna, uji coba yaitu pada tahap ini, dilakukan pengujian prototype sistem oleh pengguna kemudian dilakukan evaluasi sesuai dengan kekurangan-kekurangan dari kebutuhan pelanggan. Jika sistem sudah sesuai dengan prototype, maka sistem akan diselesaikan sepenuhnya. Namun, jika masih belum sesuai kembali ke tahap pertama.

2. Melakukan penelitian pustaka yang terdiri dari kajian literatur, pengumpulan data yang terdiri dari melakukan wawancara, pengamatan, dan tinjauan pustaka, kemudian identifikasi kebutuhan sistem yaitu terdiri dari kebutuhan fungsional dan non fungsional. Tahapan kedua design yaitu melakukan design UML seperti usecase diagram, activity diagram, dan class diagram, kemudian design interfaces seperti form-form yang akan ditampilkan di aplikasi pemetaan lokasi pelayanan kesehatan. Tahapan ketiga implementation yaitu melakukan pembuatan coding program menggunakan bahasa bahasa pemrograman Java. Aplikasi ini dibuat berbasis Android. Tahapan keempat pengujian sistem aplikasi pemetaan lokasi pelayanan kesehatan ini menggunakan pengujian ISO 25010.

3. Aplikasi ini, dibuat dengan menggunakan Android Studio serta bahasa pemograman Java dengan operating system (OS) Android. OS Android sangat fleksibel dan dapat digunakan pada berbagai platform hardware dan mudah penggunaannya. Aplikasi ini menyediakan informasi letak serta posisi geografis rumah sakit, puskesmas dan klinik utama di Way Kanan.

4. Berdasarkan hasil implementai yang dilakukan dengan penerapan ISO 25010 testing maka diperoleh sebuah hasil dari perhitungan. Aspek functional suitability mendapatkan hasil $100 \%$, usability mendapatkan hasil $81.6 \%$. Maka diperoleh kesimpulan rata - rata hasil perhitungan dari beberapa aspek yang telah dilakukan pengujian mendapatkan hasil 90,8\% yang artinya sistem yang penulis implementasikan sangat layak untuk digunakan oleh masyarakat way kanan.

\subsection{Saran}

Berdasarkan kesimpulan dari hasil penelitian yang telah diuraikan, maka saran yang dapat diberikan untuk pengembangan lebih lanjut agar diharapkan adalah sebagai berikut:

1. Sistem dapat dikembangkan lagi tidak hanya di Kabupaten Way Kanan saja, melainkan dapat berkembang untuk provinsi Lampung.

2. Pengumpulan data dapat dilakukan dengan cara scraping dan web crawling. Menurut penelitian yang dilakukan oleh [10][27] pengumpulan data dengan cara scraping dan web crawling lebih efektif karena cakupan data yang diperoleh lebih luas.

3. Saat mendeteksi koordinat, untuk mempersingkat waktu, pendeteksian koordinat dilakukan pada saat splash screen berjalan.

4. Perlu penambahan jumlah koordinat di dalam aplikasi ini agar penempatan posisi lebih akurat.

\section{Daftar Pustaka}

[1] A. Ferico Octaviansyah Pasaribu, Dedi Darwis, Agus Irawan, Ade Surahman. (2019). Sistem informasi geografis untuk pencarian lokasi bengkel mobil di wilayah Kota Bandar Lampung. Fakultas Tekhnik dan Ilmu Komputer, Universitas Teknokrat Indonesia.

[2] Adi Sucipto, Imam Danang Hermawan. (2017). Sistem Layanan Kesehatan Puskesmas menggunakan Framework Yii. Program Studi Informatika, Universitas Teknokrat Indonesia.

[3] Aditya, Ivan. (2017). Auditor Hitam. Artikel. Posting pada 02 Juni 2017. Dari http://krjogja.com dengan keyword browser 'audit hitam'. Diakses pada 4 agustus 2019. Link lengkap http://www.krjogja.com/web/news/read/34456 /Auditor_Hitam.

[4] Andi.(2013).Android Programming with Eclipse.Yogyakarta:Wahana Komputer

[5] Android Developers, 2014, Refernce http://developer.android.com/reference/java/ util/ Timer.html, diakses pada tanggal 07 Agustus 2019.

[6] Android Studio Overview. [Online]. Tersedia : http://developer.android.com/tools/studio/index.h tml, diakses pada tanggal 22 februari 2020.

[7] Andry. 2011. Android A sampai Z. PCplus, Jakarta.

[8] Ari Amir, Burham Isnanto. 2014. Prototipe Aplikasi Untuk Mengetahui Tata Letak Atm Di Pangkalpinang Pada Smartphone Android. Teknik Informatika STMIK Atma Luhur Pangkalpinang.

[9] Chandra. (2005). Coreldraw dan Photoshop untuk Grafis Percetakan, Palembang: Maxikom.

[10] Alita, D., Priyanta, S. and Rokhman, N., 2019. 
Analysis of Emoticon and Sarcasm Effect on Sentiment Analysis of Indonesian Language on Twitter. Journal of Information Systems Engineering and Business Intelligence, 5(2), pp.100-109.

[11] Deddy Ackbar Rianto, Setiawan Assegaf, Erik Fernando. 2015. Perancangan Aplikasi Sistem Informasi Geografis (Sig) Lokasi Minimarket Di Kota Jambi Berbasis Android. Program Studi Teknik Informatika, STIKOM Dinamika Bangsa, Jambi.

[12] Faya Mahdia, Fiftin Noviyanto. 2013. Pemanfaatkan Google MAP API untuk Pembangunan Sistem Informasi Manajemen Bantuan Logistik Pasca Bencana Alam Berbasis Mobile Web, Jurnal Sarjana Teknik Informatika Volume 1 Nomor 1, Juni 2013. e-ISSN: 23385197.

[13] Ivan Alfatih Saputra. 2017. Aplikasi layanan bengkel mobil berbasis android di kota bandar lampung. Jurusan ilmu komputer fakultas matematika dan ilmu pengetahuan alam universitas lampung.

[14] Imaduddin Al Fikri, Darlis Herumurti, dan Ridho Rahman H. Aplikasi Navigasi Berbasis Perangkat Bergerak dengan Menggunakan Platform Wikitude untuk Studi Kasus Lingkungan ITS. JURNAL TEKNIK ITS Vol. 5, No. 1, (2016) ISSN: 2337-3539.

[15] ISO /IEC, 25010. (2011). International Standard ISO / IEC (Vol. E).

[16] Mahatir Mohamad, Imam Ahmad, Yusra Fernando. (2017). Pemetaan Potensi Pariwisata Di Kabupaten Waykanan Menggunakan Algoritma Dijkstra. Universitas Teknokrat Indonesia.

[17] Maliki, Reza, and Kemas Wiharja. Implementasi Iso 25010:2010 Untuk Evaluasi Kualitas Perangkat Lunak (Studi Kasus: I-Gracias Universitas Telkom). Universitas Telkom, (2014). Diakses 21 februari 2020.

[18] McLeod, Jr., Raymond; Schell, George P. 2012. Sistem Informasi Managemen (Terjemahan). Jakarta: Salemba Empat.

[19] Meier, Reto. 2009. Professional Android Application Development, New York: John Wiley \& Sons.

[20] Nazruddin Safaat H. 2012 (Edisi Revisi). Pemograman Aplikasi Mobile Smartphone dan Tablet PC Berbasis Android. Informatika. Bandung.

[21] Putra, Nusa.2012. Distribusinya Tanpa Dukungan Langsung Google atau dikenal sebagai Open Handset Distribution (OHD). Jakarta : Rajagrafindo Persada.

[22] Republik Indonesia. Undang-Undang Republik Indonesia Nomor 25 Tahun 2009 tentang Pelayanan Publik.

[23] Peraturan Menteri Kesehatan Republik Indonesia
Nomor 028 Tahun 2011 Tentang Klinik.

[24] Roger, S. Pressman, Ph.D. , 2012, Rekayasa Perangkat Lunak (Pendekatan Praktisi) Edisi 7 : Buku 1 “, Yogyakarta: Andi.

[25] Rosa A. S. dan M. Salahuddin. 2013. Rekayasa Perangkat Lunak Terstruktur dan Berorientasi Objek. Bandung: Informatika.

[26] Sandy Purnama, Dyah Ayu Megawaty, Yusra Fernando. (2018). Penerapan Algoritma A Star (A*) Untuk Penentuan Jarak Terdekat Wisata Kuliner Di Kota Bandarlampung. Program Studi Informatika, Universitas Teknokrat Indonesia.

[27] S. Styawati and K. Mustofa, "A Support Vector Machine-Firefly Algorithm for Movie Opinion Data Classification," IJCCS (Indonesian J. Comput. Cybern. Syst., vol. 13, no. 3, p. 219, 2019.

[28] Turban, David K, J. Lee, T. Liang, D. Turban. 2012. Electronic Commerce 7th Edition. United States : Pearson.

[29] Uswatun Hasanah, Karmila Suryani, Riska Amelia. 2017. Perancangan Sistem Informasi Geografis Pemetaan Perguruan Tinggi Di Kota Padang Berbasis Web. Program Studi Pendidikan Teknik Informatika dan Komputer Fakultas Keguruan dan Ilmu Pendidikan Universitas Bung Hatta.

[30] Yuliana Setiowati, Afrida Helen, Istirokha, 2011, Aplikasi pelayanan dan pencarian taxi terdekat dengan cell id dan pengiriman pesan berbasis sms gateway.

[31] Yusra Fernando, Muhammad Ativ Mutsaqov, Dyah Ayu Megawaty. (2019). Penerapan algoritma $A-S T A R$ pada aplikasi pencarian lokasi fotografi di Bandar Lampung berbasis android. Fakultas Tekhnik dan Ilmu Komputer, Universitas Teknokrat Indonesia. 